\title{
SEED ENCAPSULATION IN CHITOSAN AND ITS DERIVATIVES RESTORES LEVELS OF CHLOROPHYLL AND PHOTOSYNTHESIS IN WILT-AFFECTED COTTON (Gossypium L., 1753) PLANTS
}

\author{
N.G. AKINSHINA', D.K. RASHIDOVA ${ }^{2}$, A.A. AZIZOV1
}

\author{
${ }^{1}$ Mirzo Ulugbek National University of Uzbekistan, Universitet-4 ko'chasi, Talabalar shaharchasi, Toshkent shahri, \\ 100174 O‘zbekiston, e-mail n.akinshina@yahoo.com, azazizov@rambler.ru; \\ ${ }^{2}$ Research Institute of Cotton Breeding, Seed Production and Agrotechnologies (Republic of Uzbekistan), Salar sh., \\ Qibray tumani, Toshkent viloyati, 111218 O‘zbekiston, e-mail etoile111@yandex.com \\ Acknowledgements: \\ The authors are grateful for technical support and equipment courtesy of the INNO-Concept GmbH (Strausberg, \\ Germany) \\ Received August 9, 2016
}

\section{Abstract}

Chitosan-based biologicals and chemicals have been proved to possess antiviral, antibacterial and antimycotic activity, and be able to stimulate plant immunity. In field trials (Tashkent region, Uzbekistan, 2015-2016) we first evaluated an impact of seed encapsulation with UzChitan, chitosan ascorbate and $\mathrm{Cu}^{2+}$-chelating chitosan synthesized by the authors' method in the Institute of Chemistry and Polymer Physics of the National University of Uzbekistan (NUUz, Tashkent) from waste of silkworm cocoon processing on photosynthetic activity at wilt (Verticillium dahliae) artificial infection and in wilt-free (healthy) crops of cotton (Gossypium L., 1753) variety Sultan. It was found that wilt-affected control plants (non-treated with chitosan derivatives) had higher specific leaf weight (SLW index), their chlorophyll content was reduced and rates of respiration and apparent photosynthesis were depressed in comparison with healthy control plants. Chlorophyll content in infected control plants was decreased by 27-30\% in terms of $\mathrm{mg} / \mathrm{g}$. Meanwhile, all plants from pretreated seeds contained more chlorophyll compared to control: the pigment content (mg/g of dry matter) was 25.5 and $17.7 \%$ higher when ascorbate and $\mathrm{Cu}^{2+}$-chelating chitosan used. Chlorophyll content in leaves did not vary significantly in absence of the pathogen. The apparent photosynthesis rate in control under wilt was reduced by $33 \%\left(0.161 \pm 0.027\right.$ against $\left.0.245 \pm 0.028 \mu \mathrm{mol} \mathrm{O} \mathrm{O}_{2} \cdot \mathrm{m}^{-2} \cdot \mathrm{sec}^{-1}\right)$. That corresponds to toxic effect of pathogen which penetrates through roots and goes up into top parts of plants, damages their phloem system, disturbs water transport, and destroys chlorophyll and leaf tissues. Besides, some tendency to respiration rate inhibition was observed for non-treated cotton plants under wilt infection (by $22 \%$ compared to control plants from the healthy field). Net-oxygen production (apparent photosynthesis) rates in the treated groups were higher as compared to control plants under wilt; the best results were shown by ascorbate and $\mathrm{Cu}^{2+}$-chelating chitosan (54 and $46 \%$ higher, respectively). Respiration rates did not differ significantly in all groups under wilt. Oxygen balance $(\mathrm{OB})$ index, estimated as ratio between measured oxygen net-production and oxygen consumption rates, which reflects physiological status of plants under biogenic stress (including pathogen fungi), did not change significantly in a healthy environment when chitosan derivatives used. Under wilt, the plants from pre-treated seeds possessed higher OB indices than the corresponding control plant from the same field. Thus, the $\mathrm{OB}$ values with ascorbate and $\mathrm{Cu}^{2+}$-chelating chitosan were higher compared to control by 36 and $52 \%$, respectively. Our findings indicate that in case the cotton seeds were pre-treated with chitosan derivatives, the oxygen production, oxygen consumption and OB indices were not significantly different in the pathogen-affected and unaffected plants. Thus we can conclude about a nonspecific resistance of cotton plants to wilt (Verticillium dahliae) induced by chitosan derivatives, and reduction of toxic effects of the pathogen which manifests itself in decreasing respiration and photosynthesis rates. Possibly, it is a result of non-specific elicitor activity of chitosan and its derivatives, or their ability, due to natural polycation properties, to stimulate plants to produce specific antifungal metabolites - reactive oxygen species and phytoalexins triggering subsequent defense mechanisms. Currently, using elicitors for plant immunity correction are considered promising as they contribute to formation sustainable agrophytocenosis with high adaptiveness and yield production.

Keywords: chitosan, chitosan derivatives, cotton plant, verticilliose, chlorophyll, oxygen production, respiration, oxygen balance index 
Poly-(1-4)-2-amino-2-deoxy- $\beta$-D-glucan (chitosan) is a common natural mucopolysaccharide. It can be derived from deacetylation of chitin, which is a component of the cell wall of some fungi, the exoskeleton of crustaceans, insects and worms [1]. Due to the high biological activity, chitin, chitosan and their derivatives are widely used in biomedicine and agriculture [1,2], in particular, in plant growing to protect plants against pests and diseases, for the biological control of pathogens by activating the action of antagonistic microorganisms, to enhance favorable interactions between the plant and a symbiotic microorganism, for regulating plant growth, and to increase crop yield. Preparations obtained from chitosan and its derivatives are used in the pre-planting treatment of the seeds, they are introduced into the soil, or used to spray plants or harvest [1, 3-6]. Chitosan is safe for humans, farm animals, and the environment since it naturally decomposes with associated formation of the simple monosaccharide D-glucosamine [1, 7].

It is shown that chitosan-based formulations possess antiviral, antibacterial and antimycotic activities, and are able to stimulate the immune system of the plants [1, 3, 5-8]. For example, increased disease resistance has been established in rice, tobacco, yam [2], tomato [9], soybean [10], cotton [11], wheat, barley [2, 12-15], carrots [2, 14], cucumber, and potato [8, 14]. Pre-planting seed treatment and spraying of plants lead to the oppression of grey leaf spot (Pyricularia grisea) [1, 16], root rot caused by Fusarium spp. [1, 9-11, 13, 14], Bipolaris spp. [13, 17], to the suppression of late blight (with Phythophtora parasitica and Phytophthora infestans being causative agents [Mont.] De Bary) [14], dark brown or net blotch (Bipolaris sorociniana, Drechslera teres), Septoria spot (Septoria nodorum), dusty smut (Ustilago nuda), leaf rust (Puccinia recondita), leaf mold (Cladosporium herbarum), Alternaria spot (Alternaria tenuis) [12, 13, $17,18]$. The antimicrobial effect of chitosan oligomers is related to their ability to influence the reproductive mechanism in microorganisms [7] and augment the antibiotic susceptibility. Low molecular weight chitosan is the most active against a number of bacteria, while highly deacetylated chitosans are the most effective antimicrobial agents $[1,2,7]$.

Chitosan is assigned to strong elicitors, i.e. substances that induce innate immunity in plants, causing the accumulation of antipathogenic substances by increasing expression of the protective genes $[1,2,19,20]$. It is considered that chitosan elicitor activity is based on the presence of $\mathrm{N}$-acetylglucosamine residues in its molecule, capable to interact specifically with receptors on the plant cell surface, as well as on their non-specific interaction with external and internal cellular components $[1,2]$. Polycationic nature of chitosan enables it to bind to negatively charged cytoplasmic membrane via electrostatic interactions, penetrate into the cytoplasm and the nucleus, interact with nucleic acids by disrupting normal DNA binding to histones and causing breaks of DNA strands [21]. Changes in DNA can become a signal to activate the repair processes and transcription of the protective genes. Chitosan, being a polycation, is also allegedly able to block viral replication by directly interacting with a negatively charged virus RNA [8]. Chitosan and its positively charged derivatives promote the production of antifungal metabolites in plants, in particular reactive oxygen species and phytoalexins $[9,20]$. The antiviral effect of chitosan is also associated with the ability to increase the content of reactive oxygen species that can destroy the protein coat or the genomic RNA of the virus [8]. Non-specific action of glucosamine residues underlies the ability of chitosan to inhibit infection regardless of the pathogen [2]. The combined (specific and non-specific) effects of chitosan allow the plant to reliably capture the chitosan signal and activate defensive reactions with different mechanisms of activation and action [2]. 
Plant yielding capacity and biological productivity are determined by a combination of complex interactions between physiological (photosynthesis, growth and respiration) and biochemical processes, environmental conditions and agricultural methods of cultivation, while the major role in the crop formation is assigned to photosynthesis.

As one of the manifestations of verticullium vilt in plants is leaf damage, their shrinkage and abscission, it seemed interesting for us to study some of the indicators of the leaf blade state, chlorophyll content, respiration rate and apparent photosynthesis in cotton plants affected by wilt, using PlantVital_5030 device, which allows to quite promptly perform instant diagnosis. Such investigations on cotton plant were made for the first time. Here, we have assumed that the indices that characterized important physiological processes, such as photosynthesis and respiration, objectively reflected the physiological state of the plant and, consequently, the efficacy of chitosan preparations for increasing the resistance of plants to this pathogenic fungus.

The objective was to study the effects of chitosan-based products on the photosynthetic activity in wilt affected plants.

Technique. The field trials (Tashkent region, Uzbekistan, 2015-2016) were carried out on the Sultan variety of cotton plant. Before planting, the seeds were treated with chitosan derivatives using an encapsulation technique [11]. All the products used in the investigation were synthesized in the Institute of Chemistry and Polymer Physics of the National University of Uzbekistan (NUUz, Tashkent) from the waste of silkworm cocoon processing obtained by the proprietary methodology. The four following plant groups were investigated: group I included control plants (with no pre-planting treatment); groups II, III and IV included plants treated with UzChitan (a mixture of chitosan solution and sodium carboxymethyl cellulose), chitosan ascorbate and $\mathrm{Cu}^{2+-}$ chelating chitosan complex, respectively. In each group, one part of the plants was grown on artificially infected soil (Verticillium dahliae), and the other one on the wilt-free (uncontaminated) soil. In mid of the vegetation season in the active phase of the flowering (late August), top and well illuminated leaves from the $3^{\text {rd }}$ and $4^{\text {th }}$ internodes (counting from the top) were taken at 7:30 am for the investigation.

A conventional weight method (drying at $105{ }^{\circ} \mathrm{C}$ ) was used to measure water content in the leaves [22], with further calculation of leaf mass per area (LMA) [23].

The amount of a and $\mathrm{b}$ chlorophylls were determined spectrophotometrically (Spectroquant NOVA400, Merck, Germany) [24, 25] after rapid homogenization of the leaf cuttings, dried at room temperature, in a porcelain mortar and the extraction using $85 \%$ cold aqueous solution of acetone. The content of chlorophylls (on a wet weight basis, on a dry weight basis, as well as per $1 \mathrm{~cm}^{2}$ of the leaf surface) was calculated by the Roebbelen method.

The rate of oxygen absorption by leaves at night and the rate of oxygen release in the light (apparent photosynthesis) were measured using a PlantVital_5030 apparatus (INNO-Concept GmbH, Germany) and a Clark-type electrochemical sensor (MF 41-INN Sensortechnik Meinsberg) at a temperature of $27{ }^{\circ} \mathrm{C}$. An investigated sample was illuminated by a diode which operated in the red spectrum $(\lambda=635-650 \mathrm{~nm})$. Oxygen balance was calculated as the ratio of the apparent photosynthesis to the rate of respiration at night [26-28].

The data were processed using the Ori-ginPro 7.5 software (OriginLab Corp., USA). The figures and the table show mean values of at least 20 measurements and their standard deviations. The significance of differences between mean values was calculated by single-factor analysis of variance (ANOVA) at a significance level of $\mathrm{P}=0.05$. The paper discusses the significant differences 
that meet $\mathrm{P}<0.05$.

Results. Many researchers indicate a significant reduction in the photosynthetic activity in plants affected by pathogenic fungi that may be associated with a decrease in the assimilation surface due to necrosis of the leaf tissues or proliferation of the mycelium, the destruction of chloroplasts, reduction in the chlorophyll content, and abnormal efflux of photosynthetic products because of the phloem damage [29-31]. Meanwhile, the positive effects of chitosan on plant growth and development have been described, in particular the effect on the content of photosynthetic pigments. It has been shown that the introduction of chitosan into the soil in the early stages of development of soybean, beans, tomato, rice, lettuce enabled to enhance the growth of roots and shoots, increase the leaf size and the chlorophyll content, resulting in higher yields [32, 33].

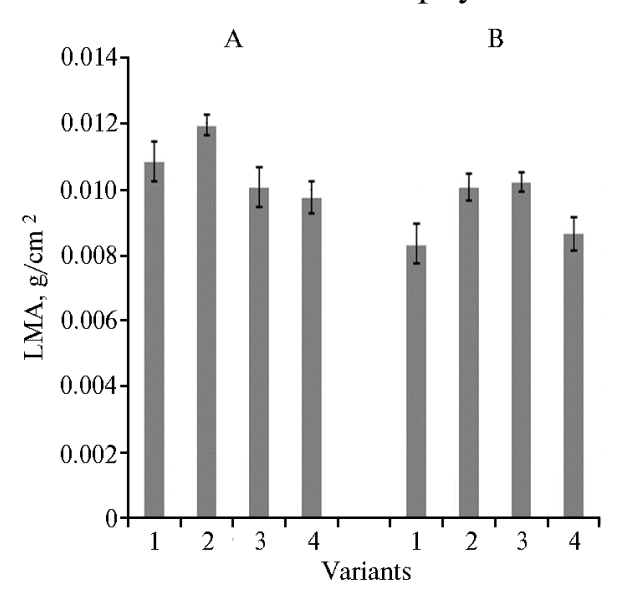

Fig. 1. Leaf mass per area (LMA) in cotton (Gossypium L., 1753) variety Sultan under the pre-planting seed treatment using chitosan-based products: $\mathrm{A}-$ artificial inoculation (Verticillium dahliae), B - without infection; 1 - control (no treatment), 2 - UzChitan (a mixture of chitosan solution and sodium carboxymethyl cellulose), $3-$ chitosan ascorbate, $4-\mathrm{Cu}^{2+}$ chelating chitosan complex (field trials, Tashkent region, Uzbekistan, 2015-2016).

The lower the specific leaf mass, the less photosynthetic products are spent by the plant to form the foliage and the faster the plant is growing and developing [23]. Taking into account that cotton wilt affects the vascular system of plants, violates the water exchange and, eventually, leads to leaf drying, it can be assumed that Verticillium dahliae causes an increase in the specific leaf mass mainly due to the slowdown of the efflux of assimilates and their accumulation in the leaf.

Of note, under the use of chitosan ascorbate, dry matter content in the leaves was almost the same in plants grown on the "pure" and infected fields (10.2 and $10.1 \mathrm{mg} / \mathrm{cm}^{2}$, respectively).

Expectedly, the content of chlorophyll pigments in the plants not infected with Verticillium was higher (Fig. 2). Under inoculation the total amount of chlorophyll $\mathrm{a}$ and $\mathrm{b}$ in the control was reduced by $10 \%$ (per $\mathrm{cm}^{2}$ of the leaf surface) or 27-30\% (per gram of dry weight) as compared to control in the absence of infection. On average, the chlorophyll level in the artificially infected plants was lower than in the uninfected ones (by $13 \%$ or $52.45 \pm 2.20$ vs. $59.31 \pm 3.05 \mu \mathrm{g} / \mathrm{cm}^{2}$, and $27 \%$ or $4.90 \pm 0.46$ vs. $6.35 \pm 0.35 \mathrm{mg} / \mathrm{g}$ dry weight). In wilt disease, the chlorophyll content after the pre-treatment with biopolymers 
was higher than in the control: by $25.5 \%$ and $17.7 \%$ (per gram of dry weight) for ascorbate or chelating complex, respectively, and by $15.0 \%$ and $16.0 \%$ (per leaf area unit) for UzChitan or ascorbate (see Fig. 2).

A
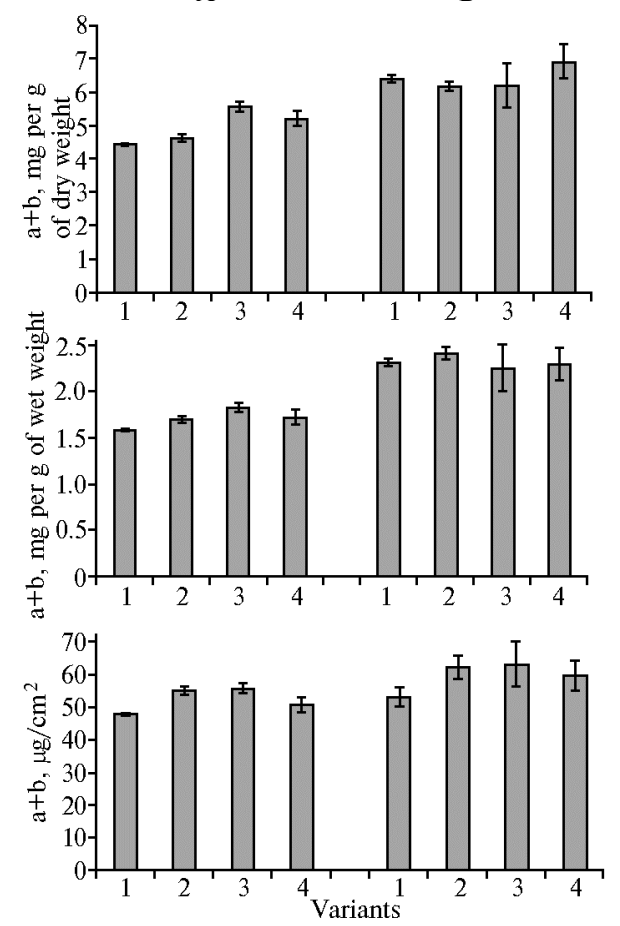

Fig. 2. The content of chlorophyll $a$ and $b$ in the leaves of cotton (Gossypium L., 1753) variety Sultan under the pre-planting seed treatment with chitosan-based products (calculated per weight and unit area): A - artificial inoculation (Verticillium dahliae), B - without infection; 1 - control (no treatment), 2 - UzChitan (a mixture of chitosan solution and sodium carboxymethyl cellulose), 3 - chitosan ascorbate, $4-\mathrm{Cu}^{2+}$-chelating chitosan complex (field trials, Tashkent region, Uzbekistan, 2015-2016). crease in the rate of photosynthesis and respiration may also be a consequence of the closing of stomata resulted from Verticillium wilt.

Absorption and release of $\mathrm{O}_{2}$ by leaves of cotton (Gossypium L., 1753) variety Sultan affected by Verticillium wilt under the pre-planting seed treatment with chitosanbased products ( $X \pm \sigma$, field trials, Tashkent region, Uzbekistan, 2015-2016)

\begin{tabular}{|c|c|c|c|}
\hline \multirow{2}{*}{ Treatment } & \multicolumn{2}{|c|}{ Rate, $\mu \mathrm{mol} \mathrm{O}{ }_{2} \cdot \mathrm{m}^{-2} \cdot \mathrm{sec}^{-1}$} & \multirow{2}{*}{ Oxygen balance index } \\
\hline & dark respiration & apparent photosynthesis & \\
\hline & \multicolumn{2}{|c|}{ Artificial infection (Verticillium dahliae) } & \\
\hline Control (no treatment) & $-0.148 \pm 0.036$ & $0.161 \pm 0.027$ & $1.092 \pm 0.209$ \\
\hline UzChitan & $-0.156 \pm 0.061$ & $0.221 \pm 0.052$ & $1.539 \pm 0.373$ \\
\hline Chitosan ascorbate & $-0.166 \pm 0.022$ & $0.248 \pm 0.051$ & $1.486 \pm 0.138$ \\
\hline Chitosan chelating complex & $-0.143 \pm 0.019$ & $0.235 \pm 0.032$ & $1.660 \pm 0.211$ \\
\hline \multicolumn{4}{|c|}{ Without infection } \\
\hline Control (no treatment) & $-0.190 \pm 0.041$ & $0.245 \pm 0.028$ & $1.331 \pm 0.301$ \\
\hline UzChitan & $-0.159 \pm 0.048$ & $0.235 \pm 0.051$ & $1.555 \pm 0.368$ \\
\hline Chitosan ascorbate & $-0.173 \pm 0.038$ & $0.232 \pm 0.077$ & $1.354 \pm 0.379$ \\
\hline Chitosan chelating complex & $-0.162 \pm 0.023$ & $0.253 \pm 0.023$ & $1.576 \pm 0.221$ \\
\hline
\end{tabular}

When chitosan products were applied for seed pre-planting treatment, the average rate of apparent photosynthesis (net production of oxygen) in the 
cotton plants affected by Verticillium wilt was higher as compared to that in the untreated control (see Table). The highest results were observed in the plants grown from seeds treated with chitosan ascorbate and chitosan chelating complex, i.e. by $54 \%$ and $46 \%$, respectively. The difference in the rate of dark respiration under artificial infestation with Verticillium in all control and test variants was statistically not significant at the $5 \%$ significance level.

In plants grown without artificial infestation, the observed differences in the rates of apparent photosynthesis and dark respiration were statistically not significant as compared to control. Additionally, with pre-treatment with chitosan and its derivatives, the same parameters under infestation were not significantly different from those in the respective group without infection. It can be concluded that the pre-planting treatment with biopolymers contributed to enhancing the immune status of the plants, and as a result we did not reveal pathological manifestations of the Verticillium infection in leaves and changes in the photosynthetic activity.

Previously, it has been shown that the ratio of the photosynthesis rate to respiration rate (oxygen balance index - OBI) can be used to characterize the physiological state of an adult plant under biogenic (nutrient) stress [27, 28]. In the absence of a pathogen (see Table), we have not found statistically significant changes in OBI when compared to control. However, under wilt pathogen infestation, the plants grown from seeds pre-treated with chitosan derivatives had higher OBI values than those without treatment. In particular, the use of chitosan ascorbate and chitosan chelating complex resulted in the increased OBI values (by $36 \%$ and $52 \%$ compared to control, respectively; a significance level of $5 \%$ ), reaching the OBI values found in the plants without infection. This may indicate an increase in plant resistance due to treatment with chitosan or its derivatives, and a termination of negative effects of the pathogen which depressed respiration and photosynthesis.

Thus, our results show the efficacy of pre-planting treatment (encapsulation) of cotton seeds with chitosan and its derivatives (chitosan ascorbate and $\mathrm{Cu}^{2+}$-chelating chitosan complex) to increase the immunity of cotton plants and develop resistance to Verticillium dahliae, the causative agent of wilt. Under wilt infection, the plants demonstrated an increased leaf mass per unit area, reduced content of chlorophyll level, decreased rates of respiration and photosynthesis. When seeds were pre-treated with tested products, the negative effect of the pathogen was not observed, and the content of chlorophyll, rates of photosynthesis and respiration did not differ significantly from those in non-infected plants. The products did not cause statistically significant changes in plants in the absence of Verticillium pathogen. These effects may be due to elicitor activity of chitosan and its derivatives and/or stimulation of specific antifungal metabolites - reactive oxygen species and phytoalexins. Chitosan ascorbate and $\mathrm{Cu}^{2+}{ }_{-}$ chelating chitosan complex demonstrated the highest efficacy.

\section{R E F E R E N C E S}

1. Ramirez M., Rodriguez A., Alfonso L., Peniche C. Chitin and its derivatives as biopolymers with potential agricultural applications. Biotecnologia Aplicada, 2010, 27: 270-276.

2. Kulikov S.N., V a rl a m o v V.P. Uchenye zapiski Kazanskogo GU, estestvennye nauki, 2008, t. 150, kn. 2: 43-58 (in Russ.).

3. G erasimenko D.V., Avdienko I.D., B annikova G.E., Zueva O.Yu., Var1 a m o v V.P. Prikladnaya biokhimiya i mikrobiologiya, 2004, 40(3): 301-306 (in Russ.).

4. Vasyukova N.I., Z inov'eva S.V., Il'inskaya L.I., Perekhod E.A., Cha l e n k o G.I., G e rasi mova N.G., I l' i n a A.V., V a r l a mov V.P. Prikladnaya biokhimiya i mikrobiologiya, 2001, 37(1): 115-122 (in Russ.).

5. Chirk ov S.N. Prikladnaya biokhimiya i mikrobiologiya, 2002, 38(1): 5-13 (in Russ.). 
6. Rabea E., B adawy M., Stevens C., S magghe G., Steurbaut W. Chitosan as antimicrobial agent: applications and mode of action. Biomacromolecules, 2003, 4(6): 1457-1465.

7. Kryzhanovskaya E.V., Varlamov V.P., Samuilenko A.Ya., Albulov A.I., Shi nkarev S.M., Frolova M.A., Ere mets N.K., B ond a reva N.A., Khab a rov V.B., Grin' A.V. Sel'skokhozyaistvennaya biologiya [Agricultural Biology], 2008, 6: 119-121 Available http://www.agrobiology.ru/6-2008krizhanovskaya.html. No date (in Russ.).

8. Evstig n e va T.A., P a vlova N.A., T y u t e rev S.L. Vestnik zashchity rastenii, 2012, 2: 27-33 (in Russ.).

9. B enhamou N., Lafontaine P., Nicole J. Induction of systemic resistance to Fusarium crown and root rot in tomato plants by seed treatment with chitosan. Phytopathology, 1994, 84(12): 1432-1444.

10. Prapagdee B., Kotchadat K., Kumsopa A., Visarathanonth N. The role of chitosan in protection of soybean from sudden death syndrome caused by Fusarium solani f. sp. glycines. Bioresourse Technol., 2007, 98(7): 1353-1358.

11. R a s hidova D.K. Primenenie biologicheski aktivnykh polimerov na khlopchatnike [The use of biologically active polymer chemicals at cotton cultivation]. Tashkent, 2015 (in Russ.).

12. P o p o v a E.V. Materialy Vserossiiskogo s"ezda "Zashchita rastenii v usloviyakh reformirovaniya agropromyshlennogo kompleksa: ekonomika, effektivnost', ekologichnost'» [Proc. All-Russian Congr. «Plant protection and reforming agriculture: the economy, efficiency, environmental friendliness»]. St. Petersburg, 1995: 233-234 (in Russ.).

13. Yudk in L.Yu., T a r la k ovski i S.A. Materialy Vserossiiskogo s"ezda "Zashchita rastenii v usloviyakh reformirovaniya agropromyshlennogo kompleksa: ekonomika, effektivnost', ekologichnost'» [Proc. All-Russian Congr. «Plant protection and reforming agriculture: the economy, efficiency, environmental friendliness»]. St. Petersburg, 1995: 482 (in Russ.).

14. Novozhilov K.V., Tyuterev S.L., Yakubchik M.S., Tarlakovski i S.A., Ko$10 \mathrm{~m}$ i e ts A.F., Panari n E.F., I s ma i lov E.Ya., Ga mza-Z ad e A.I., I s m a i lov V.Ya., B e g u nov I.I. Kompozitsiya na osnove vodnykh rastvorov khitozana, obladayushchaya biologicheskoi aktivnost'yu. Patent Rossiiskoi Federatsii № 2127056. Vserossiiskii NII zashchity rastenii Rossiiskoi akademii sel'skokhozyaistvennykh nauk [Bioactive composition based on aqueous solutions of chitosan. Patent of Russian Federation № 2127056. All-Russian Institute of Plant Protection of the Russian Academy of Agricultural Sciences. Appl. January 23, 1997. Publ. March 10, 1999.] (in Russ.).

15. B o i k o A.P. V sbornike: Zashchita i karantin rastenii [In: Plant protection]. Stavropol', 2000: 48-53.

16. Rodriguez A., Ramirez M., Napoles M., Carde nas R. Antifungal activity of chitosan and one its hydrolysates on Pyricularia grisea Sacc fungus. Cultivos Tropicales, 2003, 24(2): $85-88$.

17. Maksimov V.I., Krushev L.T., Savchenkov S.N. Biotekhnologiya, 1992, 4: 60-62 (in Russ.).

18. K u p ri n a E.E. Mikologiya i fitopatologiya, 2002, 36(4): 63-69 (in Russ.).

19. Vasil'e v L.A. Gibel' epidermal'nykh kletok $v$ list'yakh gorokha, vyzvannaya khitozanom. Avtoreferat kandidatskoi dissertatsii [Death of epidermal cells in pea leaves caused by chitosan]. Moscow, 2009 (in Russ.).

20. Karpun N.N., Yanushevskaya E.B., Mikhailova E.V. Formation of plants nonspecific induced immunity at the biogenous stress (review). Sel'skokhozyaistvennaya biologiya [Agricultural Biology], 2015, 50(5): 540-549 (doi: 10.15389/agrobiology.2015.5.540eng) (in Engl.).

21. Choi J.J., Klosterman S.J., Hadwiger L.A. A comparison of the effects of DNA damaging agents and biotic elicitors on the induction of plant defense genes, nuclear distortion, and cell death. Plant Physiol., 2001, 125: 752-762.

22. G ry a z nov V.P., S i r o t i n a L.V. Praktikum po fiziologii rastenii [Practical works on plant physiology]. Belgorod, 2000 (in Russ.).

23. V a s fi lo v S.P. Zhurnal obshchei biologii, 2011, 72(6): 436-454 (in Russ.).

24. Vorob'ev V.N., Nevmerzhitskaya Yu.Yu., Khusnetdinova L.Z., Yakushen k o v a T.P. Praktikum po fiziologii rastenii [Practical works on plant physiology]. Kazan', 2013 (in Russ.).

25. Metodicheskie rekomendatsii po opredeleniyu ryada soedinenii v vodnykh i rastitel'nykh ob"ektakh (Adaptirovannye metody dlya Spectroquant NOVA400) [Assay of chemical compounds in water and plant samples - Guidelines]. INNO-Concept GmbH. SHtrausberg, Germaniya, 2008 (in Russ.).

26. Azizov A., Tauschke M., Lentzsch P., Klose E., Akinshina N., Kara $\mathrm{s}$ y o v a T., S c h m i d C. Verfahren zur Bewertung der Vitalität chlorophylltragender biologischer Proben. Deutsches Patentant. DE 112006000480. IPC: G01N 33/483. INNO-Concept GmbH, Strausberg, DE. Anmeldung 06.03.2006. Veröffentlichung 30.04.2015.

27. Akinshina N.G., Azizov A.A., K a ras e va T.A., K loze E. Sibirskii ekologicheskii zhurnal, 2008, 2: 249-254 (in Russ.).

28. Akinshina N.G., Azizov A.A., Karaseva T.A., Kloze E.O. Materialy Mezhdu- 
narodnoi nauchno-prakticheskoi konferentsii «Sovremennaya fiziologiya rastenii: ot molekul do ekosistem» [Proc. Int. Conf. «Modern plant physiology: from molecules to ecosystems»]. Syktyvkar, 2007: 4-5 (in Russ.).

29. Lys e nko N.N., Che kali n E.I., Pozharski i S.M. Vestnik Orlovskogo gosudarstvennogo agrarnogo universiteta, 2013, 40(1): 70-76 (in Russ.).

30. Kushnirenko M.D., Medvedeva T.N. Fiziologiya rastenii, 1969, 16(3): 43-52 (in Russ.).

31. Mokronosov A.T. Fotosintez. Fiziologo-ecologicheskie i biokhimicheskie aspekty [Photosynthesis - eco-physiological and biochemical aspects]. Moscow, 2006 (in Russ.).

32. Sheikha S., Al-Malki F. Growth and chlorophyll responses of bean plants to the chitosan applications. European Journal of Scientific Research, 2011, 50(1): 124-134.

33. F a r o u k S., R a m a d a $\mathrm{A}$. Improving growth and yield of cowpea by foliar application of chitosan under water stress. Egyptian Journal of Biology, 2012, 14: 14-26 (doi: 10.4314/ejb.v14i1.2).

\section{Science Events FOOD CHEMISTRY}

(30 October-1 November 2016, Amsterdam, Netherlands)

This exciting new conference celebrating the $40^{\text {th }}$ anniversary of the leading international journal Food Chemistry will bring together experts and young researchers from academia, research centers, and industry to debate on the latest scientific advances in the field of food chemistry that help to shape current and future challenges in food quality, food safety, and health aspects of the food chain. These challenges are also intimately linked to the wider EU Horizon 2020 Societal Challenges related to health, food security, sustainable agriculture, maritime research and the bioeconomy.

Information: http://www.foodchemistryconference.com/ 